\title{
KOMODITI DOMINAN DAN PRODUKTIVITAS PURSE SEINE YANG BERBASIS DI TEMPAT PELELANGAN IKAN UJUNGBATU KABUPATEN JEPARA
}

\author{
Dominant Commodities and Purse Seine Productivity Based at the Ujungbatu Fish Auction \\ Place, Jepara District \\ Oleh: \\ Mohammad Imron¹, Siti Oftafia Wijayanti², Eko Sri Wiyono \\ 1Departemen Pemanfaatan Sumberdaya Perikanan, Fakultas Perikanan dan Ilmu Kelautan, Institut Pertanian Bogor \\ mohammadim@apps.ipb.ac.id \\ 2Departemen Pemanfaatan Sumberdaya Perikanan, Fakultas Perikanan dan Ilmu Kelautan, Institut Pertanian Bogor \\ s.oftawijayanti@apps.ipb.ac.id \\ ${ }^{3}$ Departemen Pemanfaatan Sumberdaya Perikanan, Fakultas Perikanan dan Ilmu Kelautan, Institut Pertanian Bogor \\ eko_ipb@yahoo.com
}

* Korespondensi:mohammadim@apps.ipb.ac.id

Diterima: 21 Desember 2020; Disetujui: 9 Februari 2021

\begin{abstract}
Fishing with purse seine fishing gear has been carried out by many fishermen, which are generally aimed at catching pelagic fish. Jepara District is one of the coastal areas of the North Coast of Java, located in Central Java Province. This condition makes Jepara Regency have a marinebased economic side of life which has the potential of fish resources that have been used by local fishermen for a long time. The current condition has a tendency to decline in production, which is thought to be due to overfishing. This study aims to obtain an overview of the dominant fish caught by the purse seine and to see the productivity of the purse seine. The research method used is a survey method, by conducting interviews with 20 fishermen, the head of the Ujungbatu Fish Auction Place (TPI) and his staff. The data obtained are data on catch production, composition of types of catch and other data. The results are expected to be able to provide an overview of the dominant fish catch and productivity of purse siene in the waters of Jepara District. The conclusion that can be drawn from this research is that there are three types of fish that are dominant catch, namely layang fish, mackerel and squid. During the last five years (from 2015 - 2019), production tends to experience a significant decline. Meanwhile, the productivity has also decreased as well. Based on the calculation of the productivity level according to KEPMEN KP No.61/2014, the productivity level (2019) of purse seines that land their catch at TPI Ujungbatu Jepara is 4.45, meaning that the production produced in 2019 year is 4.45 tons per vessel 1 GT used.
\end{abstract}

Keywords: : Purse Seine, Dominant Comodity, Productivity, Jepara

\section{ABSTRAK}

Penangkapan ikan dengan alat tangkap purse seine sudah banyak digunakan oleh nelayan untuk menangkap ikan pelagis. Kabupaten Jepara merupakan salah satu daerah di pesisir Pantai Utara Jawa yang terletak di Provinsi Jawa Tengah. Kondisi tersebut menjadikan Kabupaten Jepara memiliki sisi kehidupan ekonomi berbasis kelautan dikarenakan potensi sumberdaya ikan yang telah dimanfaatkan oleh para nelayan setempat sejak dulu. Saat ini terjadi kecenderungan penurunan produksi yang diduga karena telah terjadi kelebihan penangkapan. Penelitian ini dilakukan untuk membuktikan dugaan tersebut, yaitu dengan mengidentifikasi ikan hasil tangkapan yang dominan 
tertangkap oleh purse seine serta produktivitas purse seine itu sendiri. Metode penelitian yang digunakan adalah metode survei, dengan melakukan wawancara terhadap 20 nelayan, kepala Tempat Pelelangan Ikan (TPI) Ujungbatu dan beberapa staf. Data yang diperoleh berupa data produksi hasil tangkapan, komposisi jenis hasil tangkapan dan data lainnya. Hasil penelitian diharapkan mampu memberikan status produktivitas dari alat tangkap purse seine di perairan Kabupaten Jepara. Kesimpulan yang dapat diambil dari penelitian ini terdapat tiga jenis ikan hasil tangkapan dominan yaitu ikan laying, ikan kembung dan cumi cumi. Selama lima tahun terakhir (dar tahun 2015 - 2019), produksinya cenderung mengalami penurunan yang signifikan. Sedangkan untuk produktivitasnya juga mengalami penurunan juga. Berdasarkan perhitungan tingkat produktivitas sesuai KEPMEN KP No.61 / 2014 tingkat produktivitas pukat cincin yang mendaratkan tangkapannya di TPI Ujungbatu Jepara berdasarkan ton per GT pada tahun 2019, adalah sebesar 4,45 , artinya produksi yang dihasilkan dalam satu tahun itu sebesar 4,45 ton per kapal 1 GT yang digunakan.

Kata kunci: Purse Seine, Komoditi Dominan, Prodoktivitas, Jepara

\section{PENDAHULUAN}

Sumberdaya perikanan memiliki sifat hak milik bersama dan terbuka untuk umum sehingga usaha pemanfaatan dapat memberikan keuntungan yang relatif baik (Supeni et al. 2014). Pemanfaatan yang tidak diatur dengan baik akan menyebabkan pemanfaatan cenderung berlebihan sehingga dapat mengancam kelangsungan usaha pemanfaatan itu sendiri. Alat penangkap ikan yang dioperasikan oleh nelayan di Indonesia sangat beragam (multy gears). Pernyataan ini sesuai dengan Pham et al. (2014), bahwa perikanan di pesisir Indonesia didominasi oleh usaha perikanan tangkap multy species, multy gears dan open access. Perikanan tangkap di Indonesia mayoritas melakukan penangkapan di perairan pesisir. Ayunda et al. (2018) menyebutkan bahwa tangkapan ikan di Indonesia lebih dari $80 \%$ berasal dari usaha perikanan yang menangkap ikan di area pesisir (coastal area). Purse seine adalah salah satu jenis alat penangkap ikan yang palinng banyak digunakan oleh nelayan di Indonesia. Hal ini dikarenakan alat tangkap purse seine masih diangkap yang paling efektif untuk menangkap ikan pelagis.

Purse seine adalah jaring ikan yang dirangkai dan digunakan untuk menangkap kawanan ikan dengan cara berputar-putar, sehingga ikan tidak dapat lepas baik dari samping maupun dari bawah (Aliredjo 2015; Wahyono 2003). Menurut BBPPI (2008), purse seine atau sering disebut juga pukat cincin, memiliki panjang kurang dari $300 \mathrm{~m}$. Bertumbuh subur di perairan dangkal (Laut Jawa, Selat Malaka, perairan Aceh timur) atau di sepanjang perairan pesisir pada umumnya (perikanan pesisir). Menurut BSN (2010), panjang purse seine target penangkapan ikan pelagis kecil adalah kurang dari $400 \mathrm{~m}$. Purse seine terdiri dari sayap dan kantong yang dilengkapi dengan cincin serta tali cincin. Cara pengoperasiannya dengan melingkari suatu gerombolan ikan dengan jaring, lalu jaring bagian bawah dikerucutkan hingga menyerupai mangkuk. Purse seine disebut juga pukat atau jaring kantong, karena bentuk jaring pada saat dioperasikan menyerupai kantong (Diniah 2008).

Kabupaten Jepara merupakan salah satu daerah pesisir Pantai Utara Jawa yang terletak di Provinsi Jawa Tengah. Kondisi tersebut menjadikan Kabupaten Jepara memiliki sisi kehidupan ekonomi berbasis kelautan yang berpotensi memberi sumbangsih dalam perekonomian daerah. Kedekatan dengan laut ini menjadikan banyak masyarakat Jepara berprofesi sebagai pencari ikan (nelayan) untuk mencukupi kebutuhannya sehari-hari (Hertanto et al. 2013) dan melakukan operasi penangkapan ikan sebatas di perairan tersebut (Suharno dan Widayati 2015).

Salah satu sentra perikanan skala kecil di Kabupaten Jepara adalah TPI Ujungbatu. Tempat Pelelangan Ikan (TPI) Ujungbatu adalah TPI yang masih aktif di Jepara dan menjadi tempat bagi 1673 unit penangkapan ikan mendaratkan hasil tangkapannya. Jumlah unit penangkapan di TPI Ujungbatu adalah yang terbanyak di Kaputen Jepara. Unit penangkapan ikan yang beraktivitas di TPI Ujungbatu diantaranya adalah pukat kantong, pukat cincin (purse seine), jaring insang, jaring angkat, pancing dan bubu. Selain itu, produksi ikan laut basah di TPI Ujungbatu merupakan produksi perikanan yang tertinggi di Kabupaten Jepara. Alat tangkap purse seine menjadi kontributor terbesar dari produksi tersebut. Purse seine di Kabupaten Jepara menangkap ikan pelagis kecil 
seperti ikan layang dan ikan kembung (Pujianto et al. 2013; DKP Kabupaten Jepara 2018).

Kondisi perairan pesisir Pantai Utara Jawa sudah padat lebih (Suharno dan Widayati 2015). Hal tersebut menyebabkan terjadinya penurunan potensi ikan di alam (Jaya et al. 2017). Fenomena ini dapat diartikan bahwa telah terjadi degradasi sumberdaya ikan di Laut Jawa, khususnya pesisir Pantai Utara Jawa. Suman et al. (2018) membenarkan pernyataan tersebut, bahwa telah terjadi kondisi tangkap lebih (overfishing) dalam pemanfaatan sumberdaya ikan Laut Jawa, khususnya perikanan pelagis kecil. Indikasi dari kondisi ini berupa produktivitas kapal pukat cincin (purse seine) sebagai alat tangkap utama ikan pelagis kecil semakin rendah. Ini berkorelasi dengan laporan DKP Kabupaten Jepara (2019) yang menyatakan bahwa perikanan purse seine di Kabupaten Jepara selama kurun waktu lima tahun terakhir menunjukkan kecenderungan produksi yang terus menurun, yaitu sebesar $88,21 \%$ di tahun 2019 dengan produksi 257.425 $\mathrm{kg}$ dari produksi tahun 2015 yaitu $2.182 .834 \mathrm{~kg}$. Untuk mengetahui apakah terjadinya penurunan tersebut berdampak pada penurunan komoditi dominan dan juga apakah berdampak pada produktivitas alat tangkap purse seine tersebut, maka penelitian ini perlu dilakukan.

Hasil penelitian diharapkan mampu memberikan gambaran ikan dominan hasil tangkapan dan produktivitas dari purse siene di perairan Kabupaten Jepara. Perairan Kabupaten Jepara termasuk bagian dari WPP 712, yaitu Laut Jawa. Suman et al. (2018) menjelaskan bahwa perikanan pelagis kecil di Laut Jawa dihadapkan pada kondisi tangkap lebih (overfishing). Hal ini dapat terlihat dari kecenderungan produksi yang terus menurun pada perikanan purse seine di Jepara, yaitu sebesar 88,21\% di tahun 2019 dengan produksi $257.425 \mathrm{~kg}$ dari produksi tahun
2015 yaitu 2.182.834 kg (DKP Kabupaten Jepara 2019). Penurunan ini harus menjadi perhatian bersama, khususnya nelayan sehingga diperoleh jawaban akar penyebab penurunan tersebut dan upaya mengatasinya.

Produktivitas dapat diartikan sebagai kombinasi (gabungan) produksi dan aktivitas, dimana daya produksi adalah penyebabnya, dan produktivitas mengukur hasil dari daya produksi. Tenaga produksi berarti peningkatan kekuatan, dari setiap elemen produksi (Ravianto, 1996). Menurut Menteri Kelautan dan Perikanan No. 61/KEPMEN-KP/2014, produktivitas kapal penangkap ikan ditetapkan per Gross tonnage (GT) per tahun berdasarkan perhitungan jumlah ikan yang ditangkap per kapal dalam satu tahun dibagi dengan besaran gross tonnage (GT) kapal yang bersangkutan. Penelitian ini bertujuan untuk: (1) Menganalisis ikan hasil tangkapan atau komoditi dominan dari alat penangkapan purse seine; (2) Mengitung produktivitas purse seine yang dioperasikan di perairan Kabupaten Jepara.

\section{METODE}

Penelitian ini dilakukan di TPI Ujungbatu Desa Ujungbatu dan Jobokuto Kabupaten Jepara Provinsi Jawa Tengah, pada bulan Agustus 2020. Metode penelitian yang digunakan adalah metode survei, dengan melakukan wawancara terhadap 20 nelayan, kepala Tempat Pelelangan Ikan (TPI) Ujungbatu dan staf nya. Data yang diperoleh berupa data produksi hasil tangkapan, komposisi jenis hasil tangkapan dan data lainnya. Data yang diperoleh, selanjutnya diolah dan dianalisis untuk mendapatkan tujuan tersebut. Lokasi penelitian selama penelitian, disajikan pada Gambar 1.

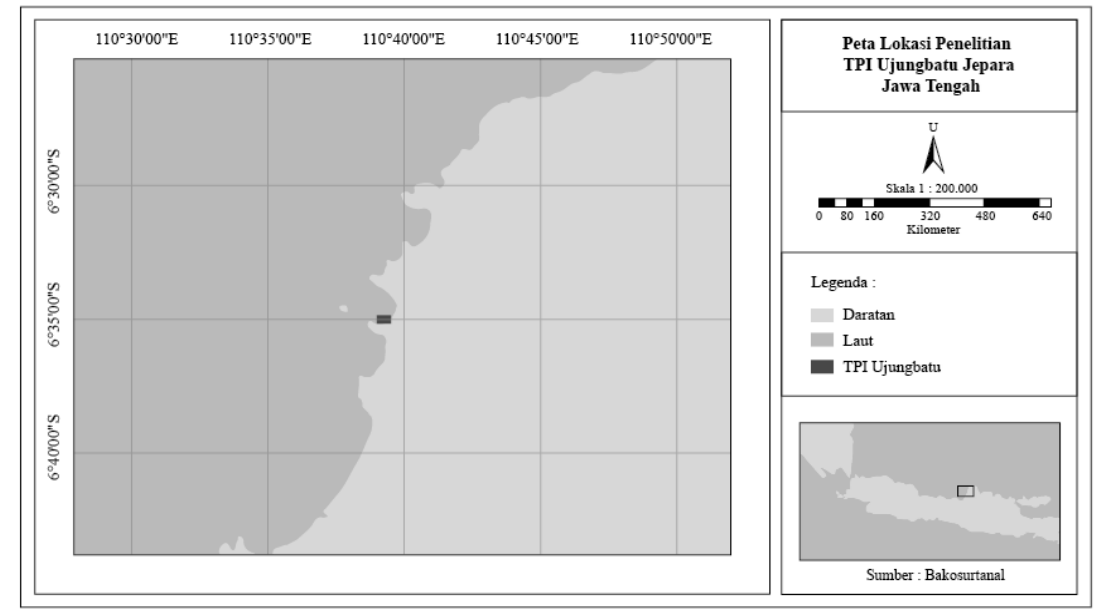

Gambar 1 Peta Lokasi Penelitian TPI Ujungbatu Jepara 
Data yang dikumpulkan pada penelitian ini terdiri atas data primer meliputi jenis alat tangkap, komposisi jenis dan produksi hasil tangkapan dominan, yang diperoleh dari hasil wawancara dan observasi lapang terhadap aktivitas pendaratan ikan di TPI Ujungbatu pada bulan Agustus 2020. Data sekunder yang dikumpulkan berupa data produksi bulanan ikan yang didaratkan di TPI tersebut. Data sekunder yang dikumpulkan mulai dari tahun 2015 hingga tahun 2019. Data komposisi ikan hasil tangkapan dominan dianalisis dengan menggunakan analisis deskriptif, yakni dengan menganalisis data ikan hasil tangkapan yang dominan tertangkap dari tahun 2015-2019.

Berdasarkan Keputusan Menteri Kelautan dan Perikanan No.61/KEPMEN$\mathrm{KP} / 2014$, produktivitas kapal penangkap ikan ditetapkan per gross tonnage (GT) per tahun berdasarkan perhitungan jumlah ikan yang ditangkap per kapal dalam satu (1) tahun dibagi jumlah gross tonnage (GT) kapal yang bersangkutan. Rumus yang digunakan adalah sebagai berikut :

Produktivitas menurut GT Kapal

$($ ton per GT $)=\frac{\Sigma \text { Produksi }}{\Sigma \text { Tonase } \text { Kapal }}$

Produktivitas menurut HP Kapal

(ton per HP) $=\frac{\Sigma \text { Produksi }}{\Sigma \text { HP Kapal }}$.

Produktivitas menurut panjang jaring

(ton per $\mathrm{m})=\frac{\Sigma \text { Produksi }}{\Sigma \text { Panjang Jaring }}$.

Produktivitas menurut jumlah ABK

(ton per orang $)=\frac{\Sigma \text { Produksi }}{\Sigma \text { Jumlah } A B K}$.

Produktivitas menurut trip penangkapan

(ton per hari) $=\frac{\Sigma \text { Produksi }}{\Sigma \text { Trip }}$.

\section{HASIL}

Perikanan purse seine di Kabupaten Jepara menggunakan kapal dengan ukuran rata-rata 19 GT. Purse seine dioperasikan hanya menggunakan alat bantu berupa lampu dan mayoritas tanpa penggunaan GPS dan fish finder. Mesin penggerak kapal masing-masing berdaya $120 \mathrm{PK}$ dengan jumlah dua mesin. Mesin penggerak ini juga berfungsi untuk menyalakan lampu di kapal purse seine. Pengoperasian purse seine dibantu oleh sekitar 23 ABK dalam sekali melaut dengan panjang jaring 300-550 m. Pengoperasian purse seine Jepara tergolong dalam one day fishing.

Rata-rata pengoperasian purse siene Jepara hanya di sekitar perairan Jepara $( \pm$ 8-12 mil), namun untuk beberapa nelayan biasanya bisa menjangkau hingga perairan Batang. Hasil tangkapan purse seine terdiri dari multy species seperti ikan kembung, ikan juwi, layang, cumi, tongkol, tengiri, bentong dan lain-lain. Ikan kembung banyak didapatkan dari pengoperasian purse seine menggunakan metode ngojek, sedangkan cumi, layang, juwi menjadi hasil tangkapan terbanyak untuk metode pengoperasian ngobor Purse Seine Jepara.

\section{Komoditas Dominan}

Hasil tangkapan Purse seine yang didaratkan di TPI Ujungbatu Jepara didominasi oleh ikan pelagis kecil, dengan didominasi oleh ikan layang, kembung dan cumi-cumi. Ikan tersebut cukup dikenal masyarakat dan juga musiman yaitu keberadaan ikan pada suatu perairan berbeda-beda pada waktu tertentu (Wahju et al. 2011). Jenis ikan tersebut termasuk ke dalam nilai ekonomis penting. Produksi ikan di TPI Ujungbatu setiap tahunnya sangat beragam baik jenis maupun jumlah hasil tangkapannya. Jumlah produksi berbeda setiap tahun. Produksi ikan TPI Ujungbatu pada tahun 2014 hingga 2019 dapat dilihat pada Tabel 1.

Berdasarkan Tabel 1, jumlah produksi diatas dapat diketahui bahwa pada tahun 20152016 produksi di TPI Ujungbatu mengalami peningkatan sebesar $37.555 \mathrm{~kg}$ menjadi $2.141 .110 \mathrm{~kg}$. Pada tahun 2015 mengalami penurunan signifikan sebesar $1.545 .645 \mathrm{~kg}$ menjadi $592.465 \mathrm{~kg}$. Pada tahun 2018 dan 2019 mengalami penurunan kembali masing-masing menjadi $438.974 \mathrm{~kg}$ dan $206.363 \mathrm{~kg}$. Secara umum, hasil tangkapan ikan layang paling dominan dibanding ikan lainnya. Dominasi ikan layang sebagai hasil tangkapan terbanyak, terjadi di setiap tahun dibandingkan ikan lainnya. Perairan laut di Kabupaten Jepara mempunyai kekayaan sumberdaya ikan dengan hasil tangkapan yang bernilai ekonomis tinggi seperti yang didaratkan di TPI Ujungbatu yaitu ikan layang, kembung dan cumi-cumi.

Data hasil produksi dibedakan berdasarkan jenis ikan per tahun di TPI Ujungbatu Jepara (Gambar 2). Produksi bulanan ikan hasil tangkapan dominan alat tangkap purse seine pada tahun 2015, adalah ikan layang dengan jumlah produksi terbanyak pada bulan Juni sebanyak $344.427 \mathrm{~kg}$ dan yang paling sedikit pada bulan Februari sebesar $37.997 \mathrm{~kg}$. Produksi kedua dominan terbanyak adalah ikan 
kembung pada bulan Juni sebesar $76.843 \mathrm{~kg}$ dan yang paling sedikit pada bulan Juli sebesar $3.474 \mathrm{~kg}$. Produksi ketiga dominan terbanyak adalah cumi-cumi sebesar $6.739 \mathrm{~kg}$ pada bulan Juni dan yang terkecil pada bulan Juli sebesar $125 \mathrm{~kg}$.

Pada Gambar 3, disajikan produksi bulanan ikan hasil tangkapan dominan alat tangkap purse seine pada tahun 2016. Produksi bulanan ikan hasil tangkapan dominan alat tangkap purse seine adalah ikan layang dengan jumlah produksi terbanyak pada bulan Mei sebanyak $278.933 \mathrm{~kg}$ dan yang paling sedikit pada bulan Desember sebesar $25.800 \mathrm{~kg}$. Produksi kedua dominan terbanyak adalah ikan kembung pada bulan September sebesar $38.060 \mathrm{~kg}$ dan yang paling sedikit pada bulan Juli sebesar $5.915 \mathrm{~kg}$. Produksi ketiga dominan terbanyak adalah cumi cumi sebesar $3.617 \mathrm{~kg}$ pada bulan Oktober dan yang terkecil pada bulan September sebesar $290 \mathrm{~kg}$.

Pada Gambar 4, produksi bulanan ikan hasil tangkapan dominan alat tangkap purse seine pada tahun 2017, adalah ikan layang dengan jumlah produksi terbanyak pada bulan Maret sebanyak $45.247 \mathrm{~kg}$ dan yang paling sedikit pada bulan Desember sebesar $6.550 \mathrm{~kg}$. Produksi kedua dominan terbanyak adalah ikan kembung pada bulan April sebesar $41.392 \mathrm{~kg}$ dan yang paling sedikit pada bulan Desember sebesar $645 \mathrm{~kg}$. Produksi ketiga dominan terbanyak adalah cumi -umi sebesar $4.070 \mathrm{~kg}$ pada bulan Agustus dan yang terkecil pada bulan November sebesar $195 \mathrm{~kg}$.

Pada Gambar 5, produksi bulanan ikan hasil tangkapan dominan alat tangkap purse seine pada tahun 2018, adalah ikan kembung dengan jumlah produksi terbanyak pada bulan April sebanyak $42.281 \mathrm{~kg}$ dan yang paling sedikit pada bulan Januari sebesar $360 \mathrm{~kg}$. Produksi kedua dominan terbanyak adalah ikan layang pada bulan April sebesar $37.555 \mathrm{~kg}$ dan yang paling sedikit pada bulan Januari sebesar 1.015 kg. Produksi ketiga dominan terbanyak adalah cumi-cumi sebesar $4.735 \mathrm{~kg}$ pada bulan April dan yang terkecil pada bulan Juni sebesar 535 $\mathrm{kg}$.

Pada Gambar 6, produksi bulanan ikan hasil tangkapan dominan alat tangkap purse seine pada tahun 2019, adalah ikan layang dengan jumlah produksi terbanyak pada bulan Februari sebanyak $15.300 \mathrm{~kg}$ dan yang paling sedikit pada bulan Juni sebesar $609 \mathrm{~kg}$. Produksi kedua dominan terbanyak adalah ikan kembung pada bulan September sebesar $12.737 \mathrm{~kg}$ dan yang paling sedikit pada bulan Juni sebesar 473 $\mathrm{kg}$. Produksi ketiga dominan terbanyak adalah cumi cumi sebesar $2.539 \mathrm{~kg}$ pada bulan Oktober dan yang terkecil pada bulan Juni sebesar 414 $\mathrm{kg}$.

Tabel 1 Produksi Hasil Tangkapan Ikan Dominan di TPI Ujungbatu Tahun 2015-2019.

\begin{tabular}{lrrrr}
\hline Tahun & Layang $(\mathrm{Kg})$ & Kembung $(\mathrm{Kg})$ & Cumi $(\mathrm{Kg})$ & Jumlah $(\mathrm{Kg})$ \\
\hline 2015 & $1,747,303$ & 312,958 & 43,294 & $2,103,555$ \\
2016 & $1,880,030$ & 235,579 & 25,501 & $2,141,110$ \\
2017 & 320,945 & 241,946 & 29,574 & 592,465 \\
2018 & 217,793 & 191,438 & 29,743 & 438,974 \\
2019 & 117,067 & 71,587 & 17,699 & 206,353 \\
\hline
\end{tabular}

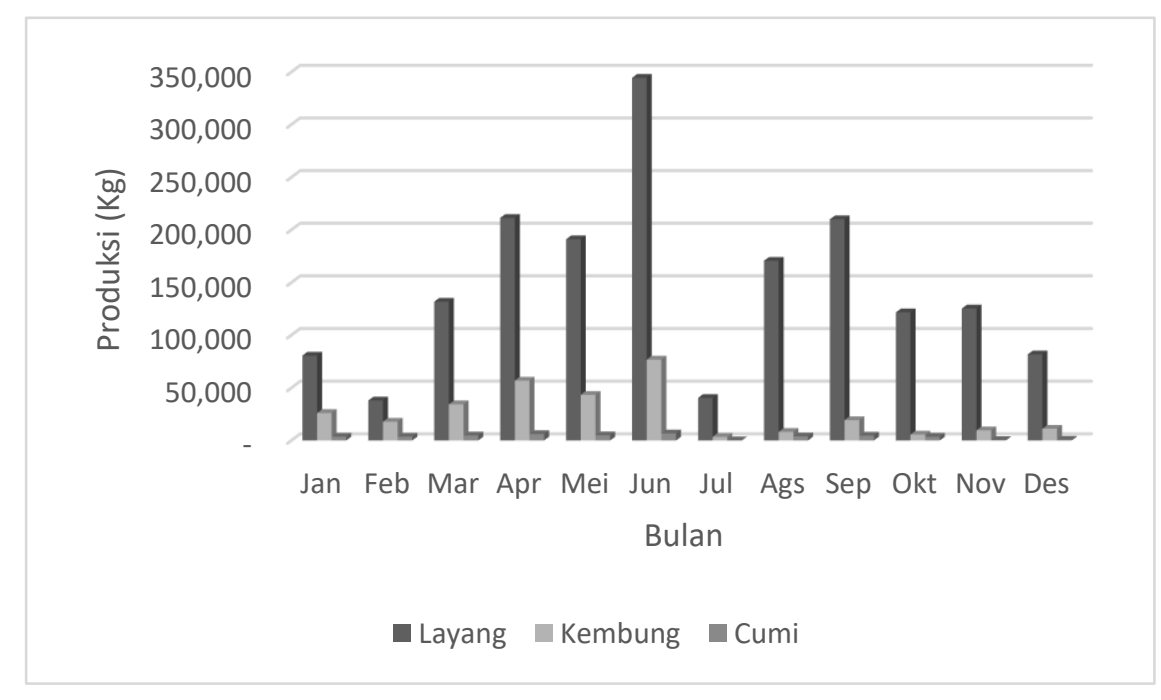

Gambar 2 Produksi Hasil Tangkapan Ikan di TPI Ujungbatu Tahun 2015 


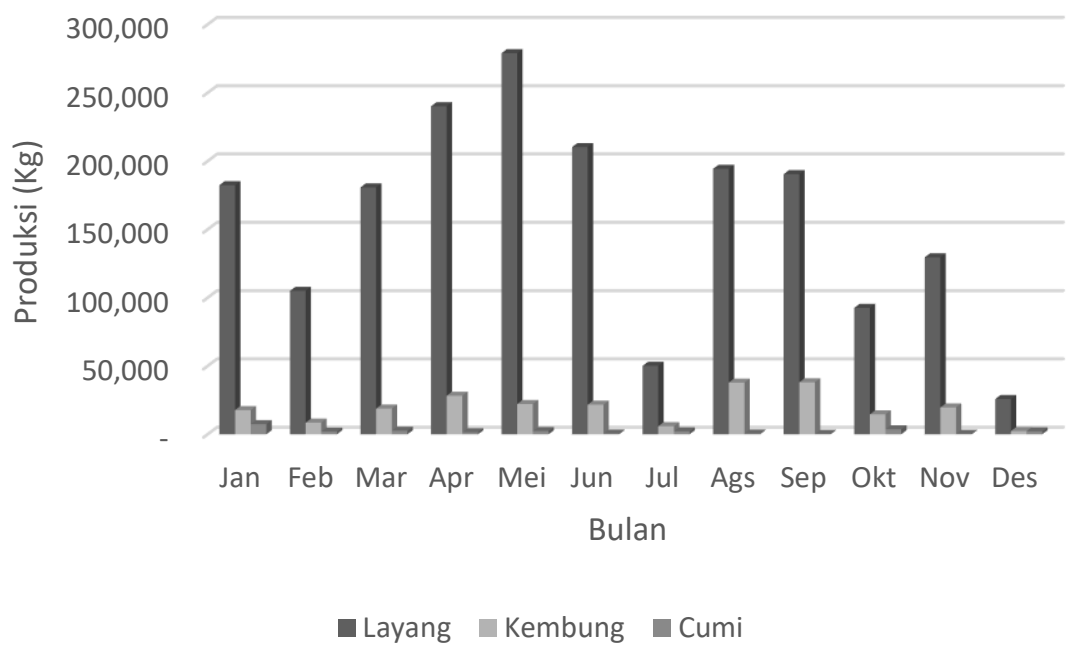

Gambar 3 Produksi Hasil Tangkapan Ikan di TPI Ujungbatu Tahun 2016.

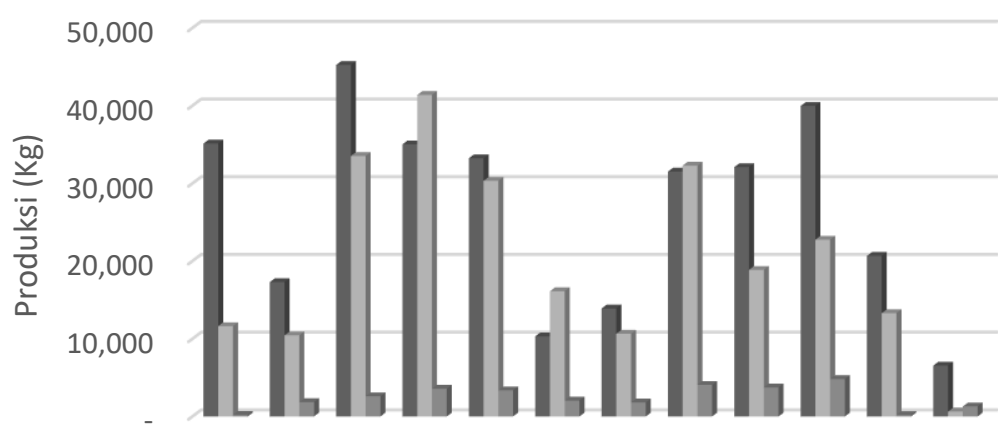

Jan Feb Mar Apr Mei Jun Jul Ags Sep Okt Nov Des Bulan

- Layang Kembung Cumi

Gambar 4 Produksi Hasil Tangkapan Ikan di TPI Ujungbatu Tahun 2017

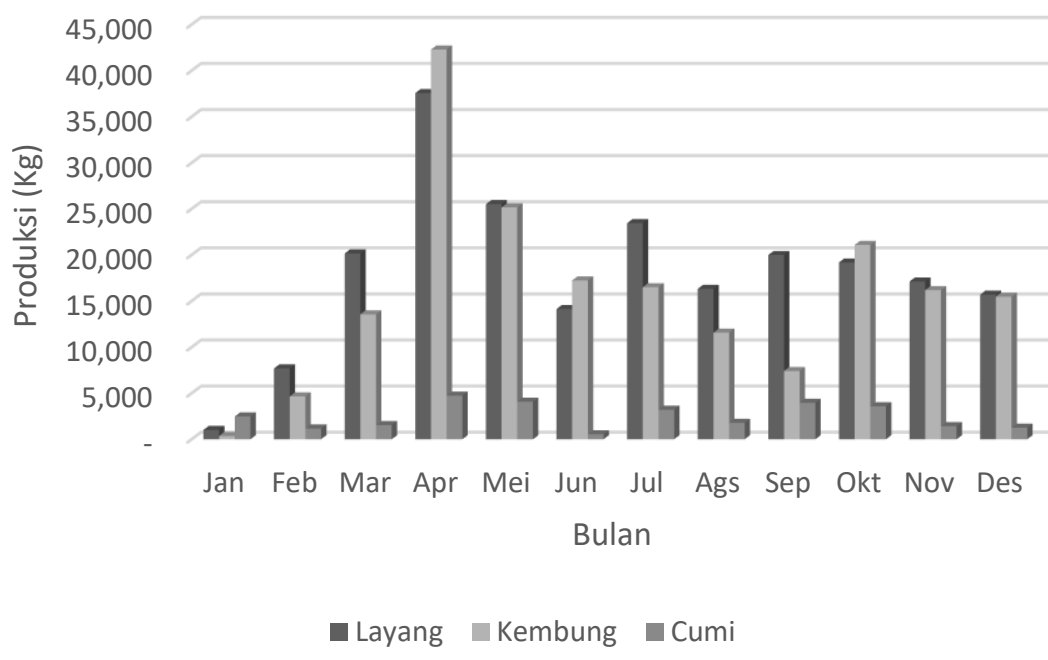

Gambar 5 Produksi Hasil Tangkapan Ikan di TPI Ujungbatu Tahun 2018 


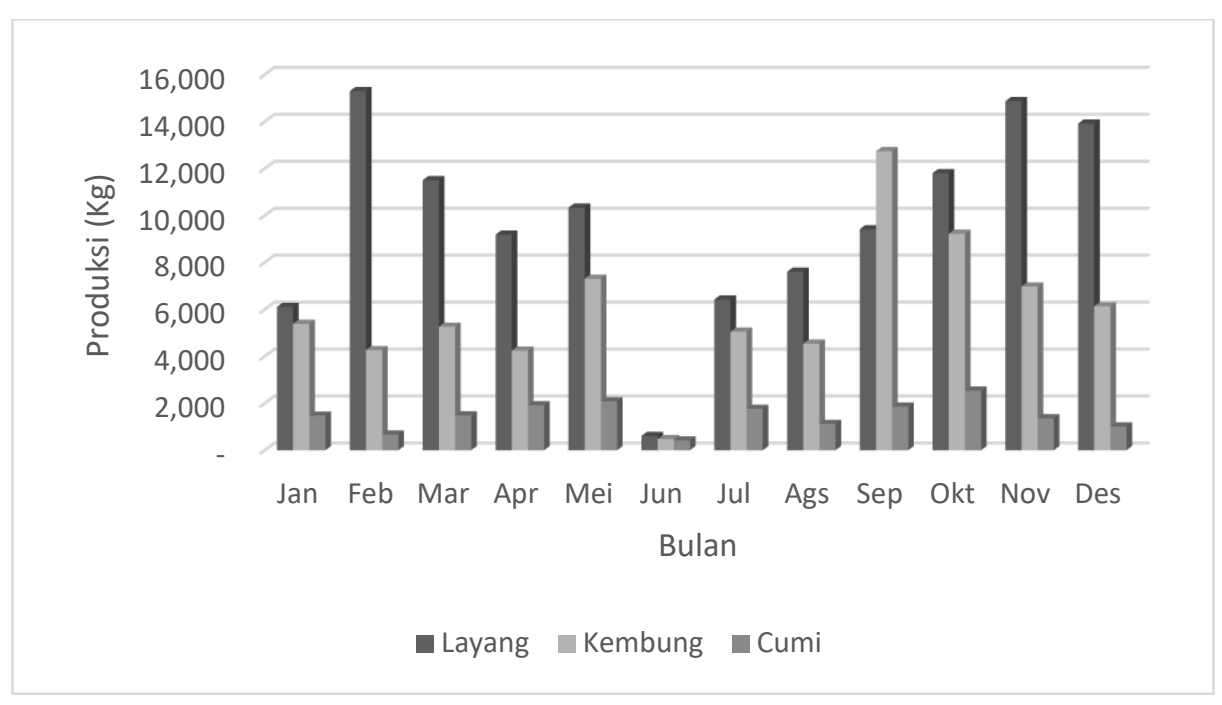

Gambar 6 Produksi Hasil Tangkapan Ikan di TPI Ujungbatu Tahun 2019

\section{Produktivitas}

Produktivitas penangkapan dapat memberikan informasi kepada nelayan mengenai tingkat kemampuan suatu alat tangkap untuk memperoleh hasil tangkapan. Kemudian informasi mengenai pola musim penangkapan dan daerah penangkapan ikan dominan sangat diperlukan untuk mempermudah operasi penangkapan menggunakan purse seine. Perolehan informasi tersebut diharapkan agar nelayan lebih efektif dalam menentukan waktu penangkapan ikan serta dapat mengurangi risiko kerugian dari usaha penangkapan. Selain itu, informasi terkait musim penangkapan juga dapat digunakan oleh pemerintah dalam mengatur armada penangkapan untuk menghindari tangkap lebih. Produktivitas penangkapan, penentuan pola musim penangkapan ikan dan daerah penangkapan purse seine terhadap jenis ikan dominan diperoleh dengan menghitung CPUE dan mengestimasi musim penangkapan ikan dan daerah penangkapan ikan hasil tangkapan purse seine yang didaratkan di TPI Ujungbatu Jepara.

Berdasarkan perhitungan tingkat produktivitas sesuai KEPMEN KP No.61 / 2014, seperti yang disajikan pada Gambar 7 , tingkat produktivitas purse seine yang mendaratkan tangkapannya di TPI Ujungbatu Jepara berdasarkan ukuran GT kapal cenderung mengalami penurunan dari tahun 2015 sampai 2019. Produktivitas pada tahun 2015 sebesar 25,73 menurun drastis menjadi hanya 4,45 pada tahun 2019 .

Berdasarkan perhitungan tingkat produktivitas sesuai KEPMEN KP No. 61/
2014, seperti yang disajikan pada Gambar 8 di atas tingkat produktivitas pukat cincin berdasarkan daya mesin (HP) yang mendaratkan tangkapannya di TPI Ujungbatu Jepara cenderung mengalami penurunan dari tahun 2015 sampai 2019. Produktivitas pada tahun 2015 sebesar 3,85 menurun drastis menjadi hanya 0,67 pada tahun 2019. Demikian pula hasil perhitungan tingkat produktivitas berdasarkan panjang jaring, mengalami penurunan drastis menjadi hanya 0,21 pada tahun 2019 (dari tahun 2015). Selain itu, penurunan tingkat produktivitas juga terjadi sebesar 0,30 dari tahun 2015 hingga 2019, berdasarkan jumlah trip penangkapan.

\section{PEMBAHASAN}

Produktivitas membahas tentang perbandingan output (produksi) dan input produksi. Input produksi seperti GT kapal, PK mesin, ABK dan trip memiliki pengaruh yang signifikan terhadap hasil tangkapan purse seine (produksi) (Alhuda et al. 2016). Tren produktivitas yang dinamis disebabkan sering berubahnya nilai output dan input produksi karena menyesuaikan kondisi yang tidak menentu. Produktivitas penangkapan dapat memberikan informasi kepada nelayan mengenai tingkat kemampuan suatu alat tangkap untuk memperoleh hasil tangkapan. Produktivitas yang tinggi dapat ditunjukkan dari besarnya nilai hasil tangkapan (produksi) yang berujung pada meningkatnya pendapatan nelayan. Selain itu, Wiyono (2010) menambahkan bahwa produktivitas yang tinggi mampu mencerminkan kelimpahan ikan yang baik dalam suatu perairan. 


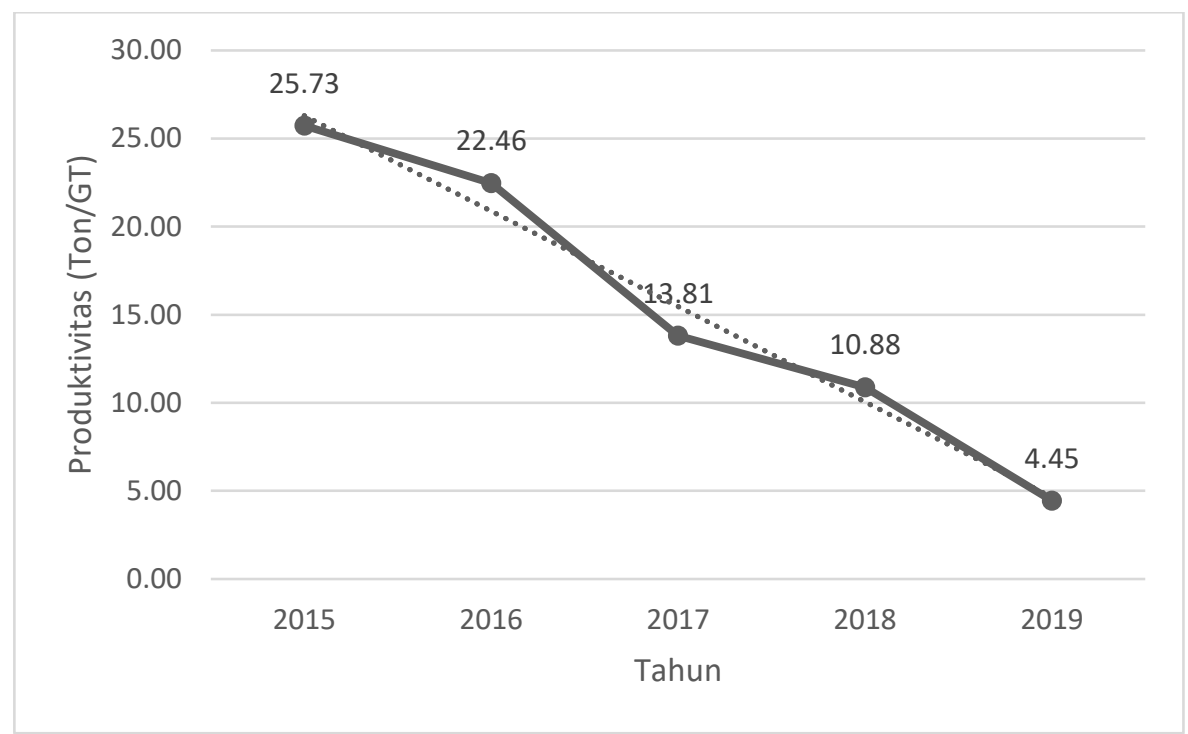

Gambar 7 Produktivitas Mini Purse Seine Berdasarkan GT (ton/GT)

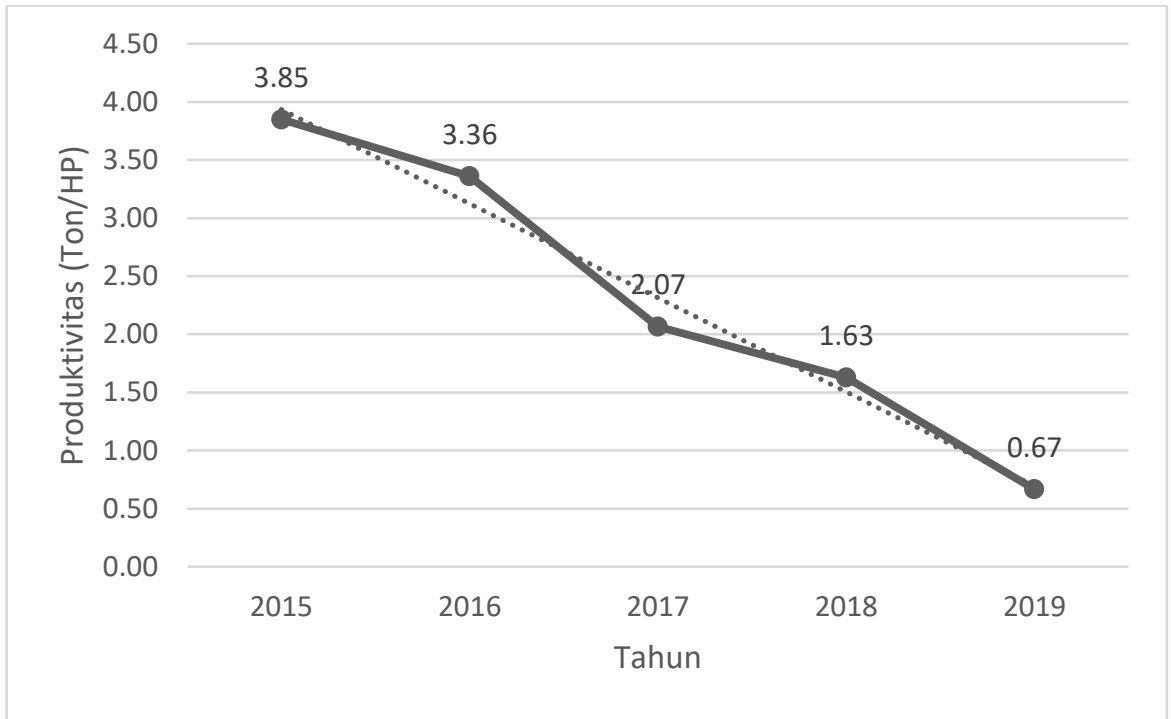

Gambar 8 Produktivitas Mini Purse Seine Berdasarkan HP (ton/HP)

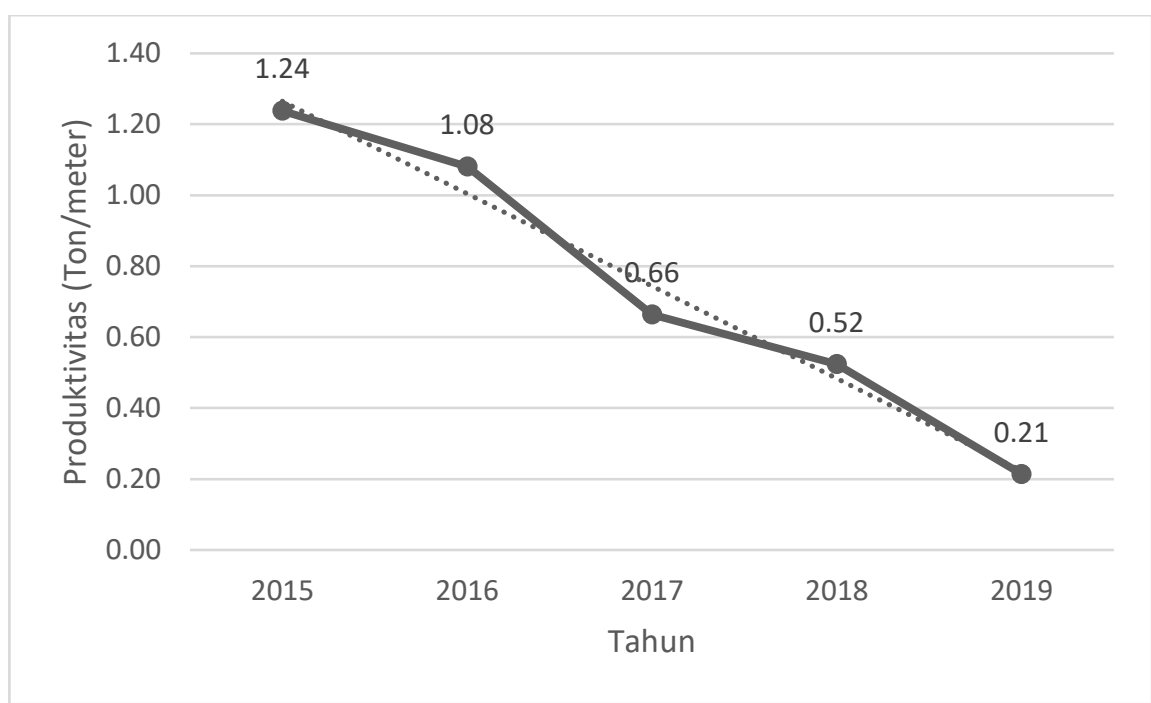

Gambar 9 Produktivitas Mini Purse Seine Berdasarkan Panjang Jaring (ton/meter) 


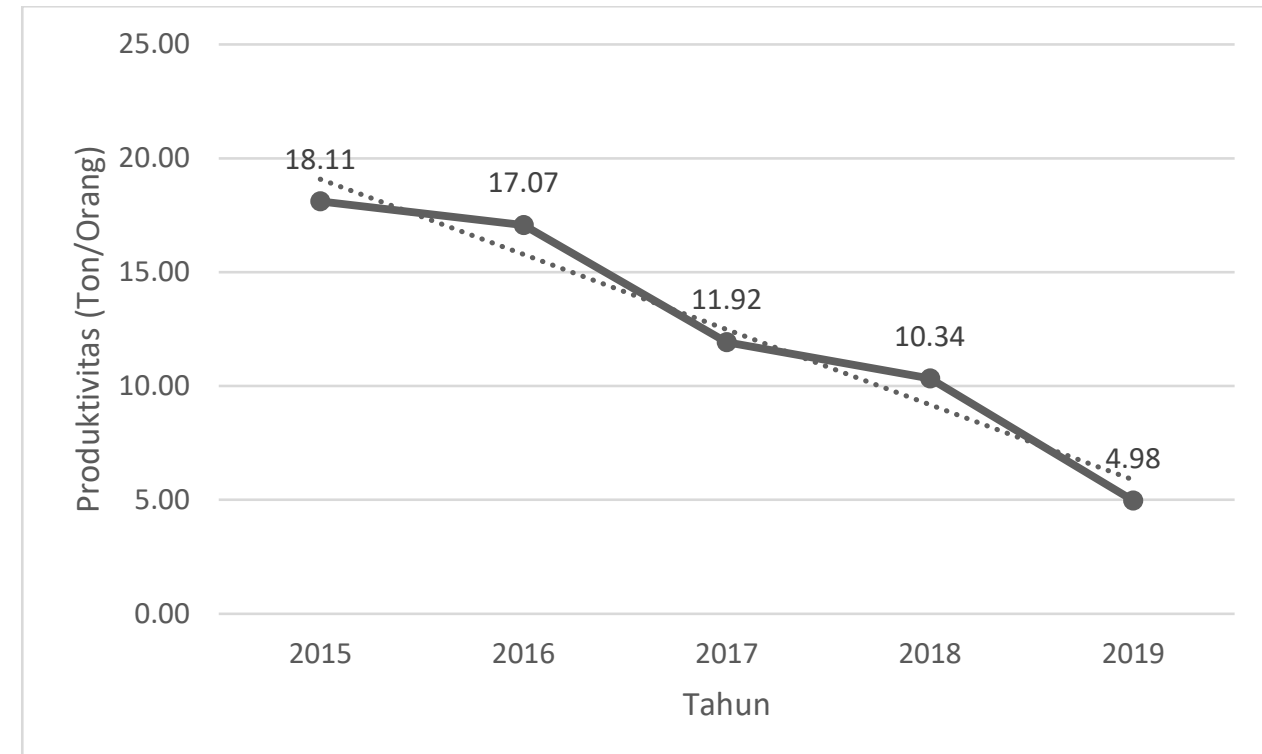

Gambar 10 Produktivitas Mini Purse Seine Berdasarkan Jumlah ABK (ton/orang)

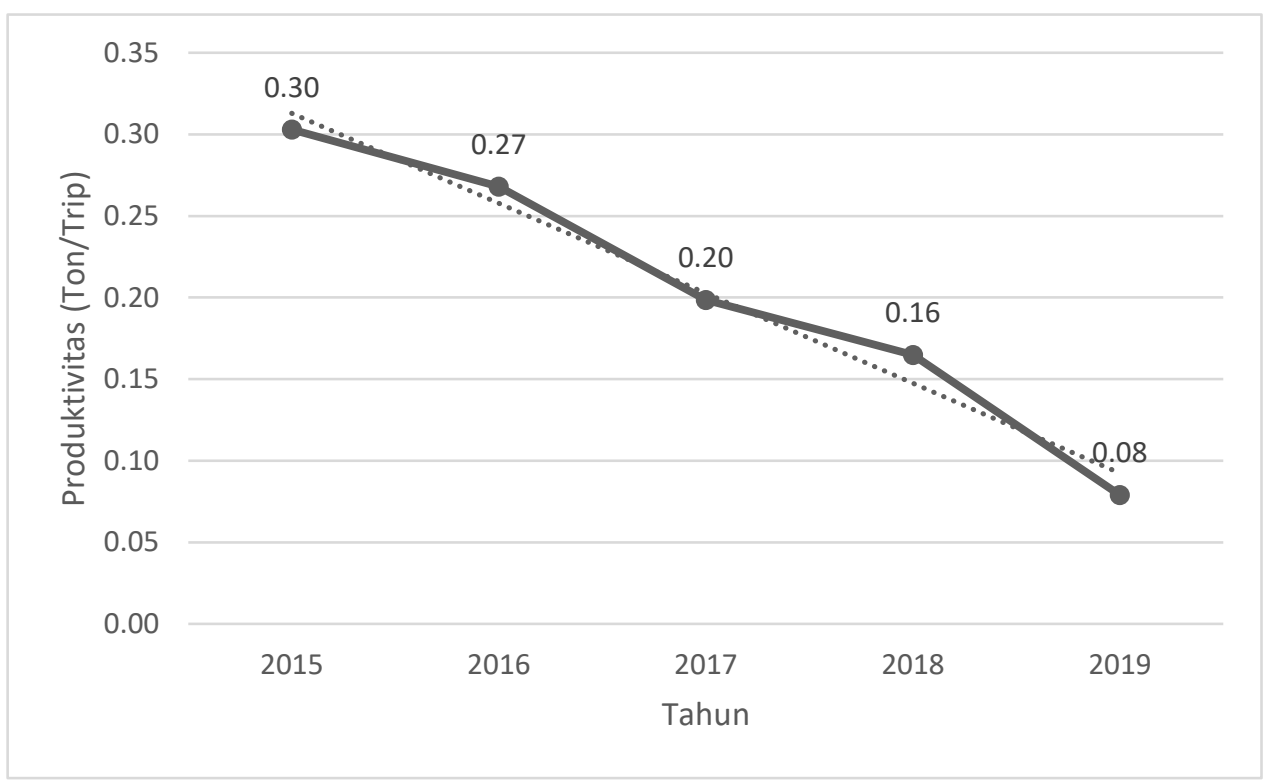

Gambar 11 Produktivitas Mini Purse Seine Berdasarkan Jumlah Trip (ton/Trip)

Produktivitas perikanan purse seine di Kabupaten Jepara mengalami tren yang cenderung menurun dalam kurun waktu lima tahun terakhir. Nilai produktivitas yang menurun ini terjadi pada semua input produksi yang meliputi produktivitas mini purse seine berdasarkan GT (ton/GT), Produktivitas mini purse seine berdasarkan HP (ton/HP). Demikian pula halnya dengan produktivitas mini purse seine berdasarkan panjang jaring (ton/meter), produktivitas mini purse seine berdasarkan jumlah ABK (ton/orang), produktivitas mini purse seine berdasarkan jumlah trip (ton/trip) juga mengalami penurunan.

Penurunan produktivitas purse seine dari tahun 2015 hingga 2019 sebesar $82,71 \%$ di Kabupaten Jepara terjadi berdasarkan ukuran GT kapal purse seine. Turunnya produktivitas ini mengakibatkan keuntungan yang diperoleh nelayan purse seine di Jepara semakin kecil. Meskipun demikian, nilai produktivitas purse seine Jepara sudah tergolong melebihi 1.20 ton/GT sebagaimana tercantum dalam Kepmen KP No. 61 tahun 2014. Damayanti (2020) menyatakan bahwa harus dilakukan pembatasan jumlah tangkapan apabila nilai produktivitas melebihi dari nilai standar peraturan. Kondisi yang bertolak belakang ini disebabkan oleh kurang optimalnya nelayan dalam penentuan input produksi. Limbong et al. (2017) menyatakan bahwa secara umum, besar kecilnya produktivitas per GT tidak berbanding lurus dengan besar kecilnya GT kapal. 
Menurut kekuatan mesin kapal, produktivitas mini purse seine mengalami penurunan $82,60 \%$ di tahun 2019 dari lima tahun terakhir. Padahal kekuatan mesin kapal yang dimiliki oleh nelayan purse seine Jepara tidak mengalami perubahan ukuran selama lima tahun terakhir. Keadaan ini diduga karena jumlah sumberdaya ikan yang semakin berkurang di daerah penangkapan ikan purse seine Jepara. Hariyanto et al. (2008) menyatakan akibat dari sumberdaya ikan yang semakin sedikit adalah penurunan produktivitas alat tangkap dikarenakan terjadinya penurunan hasil tangkapan.

Produktivitas mini purse seine berdasarkan panjang jaring adalah nilai purse seine dalam menghasilkan output yang diperoleh karena penggunaan panjang jaring purse seine. Presentase terbesar penurunan produktivitas purse seine terjadi berdasarkan panjang jaring ini, yaitu sebesar $83,06 \%$. Penurunan drastis ini dipicu kondisi alam yang sangat dinamis yang berhubungan dengan arus saat penurunan jaring serta keadaan jaring yang selalu diperbaiki, sehingga mengurangi efektivitas dalam proses penangkapan. Panjang jaring menjadi faktor produksi yang sangat berpengaruh terhadap banyak sedikitnya jumlah hasil tangkapan yang diperoleh (Alhuda et al. 2016; Fatimah 2017).

Penurunan produktivitas purse seine jepara terhadap jumlah $A B K$ selaras dengan kondisi lapangan. Jumlah ABK purse seine di Jepara dalam setiap tahunnya mengalami penurunan. Sehingga berpengaruh terhadap hasil tangkapan dan berujung pada produktivitas yang sebanding (menurun). Variable ABK adalah positif yang berarti setiap penambahan ABK maka akan meningkatkan hasil tangkapan purse seine dan juga sebaliknya (Alhuda et al. 2016).

Produktivitas mini purse seine terhadap jumlah trip berarti kemampuan purse seine untuk menghasilkan hasil tangkapan per trip. Produktivitas mini purse seine berkurang sampai $73,33 \%$ di tahun 2019 dari produktivitas di tahun 2015. Jumlah trip yang semakin banyak akan berkorelasi positif terhadap hasil tangkapan (Alhuda et al. 2016; Damayanti 2020). Penurunan ini disebabkan kurang aktifnya nelayan dalam mengoperasikan purse seine, karena tingginya kompetisi dengan pengoperasian alat tangkap lain di perairan yang sama.

Produktivitas penangkapan dapat memberikan informasi kepada nelayan mengenai tingkat kemampuan suatu alat tangkap untuk memperoleh hasil tangkapan.
Apabila daerah penangkapan ikan diketahui terlebih dahulu maka akan lebih efektif dan efisien untuk meningkatkan produktivitas penangkapan (Nurhayati et al. 2018). Nelayan bisa lebih mudah dalam proses penangkapan ikan serta dapat mengurangi risiko kerugian dari usaha penangkapan. Peningkatan usaha dan produksi penangkapan dalam jangka panjang dapat menyebabkan penurunan biomass ikan dan juga pendapatan nelayan. Informasi yang dibututuhkan juga dalam penangkapan ikan dengan purse seine adalah mengenai pola musim ikan. Saat ini sebagian besar nelayan masih mengandalkan pengalaman secara turun temurun (Wudji dan Suwarso 2015). Selain ditentukan pola musim penangkapan dari setiap jenis ikan diharapkan kegiatan penangkapan dilakukan tepat waktu dan terkendali, serta penangkapan ikan akan lebih efektif dan efisien dengan mengetahui terlebih dahulu daerah penangkapannya.

Penurunan nilai produktivitas mengindikasikan terjadinya penurunan biomassa atau sumberdaya, sebaliknya apabila nilai produktivitas meningkat mengindikasikan bahwa kondisi sumberdaya dalam kondisi baik. Dapat dikatakan bahwa kondisi biomassa di perairan Jepara pada saat ini dalam kondisi menurun karena selama lima tahun terakhir dari tahun 2015 - 2019 terjadi penurunan produksi dan produktivitas. Hal ini disebabkan karena terjadinya peningkatan aktivitas penangkapan di perairan Jepara. Berkurangnya unit penangkapan purse seine karena ada yang dijual dan bahkan mangkrak (tidak beroperasi sampai rusak), yang menyebabkan produktivitas purse seine cenderung menurun. Data tahun 2015 terdapat 25 kapal purse seine dan saat ini cuma ini hanya 18 unit saja. Faktor lainnya yang menyebabkan menurunnya produksi dan produktivitas purse seine adalah semakin bertambahnya unit penangkapan lainnya seperti arad dan cantrang. Meskipun kedua alat tangkap tersebut ditujukan untuk menangkap ikan demersal, namun demikian sedikit banyak memberikan dampak pada kondisi sumberdaya ikan secara keseluruhan. Arad dan cantrang pada umumnya menangkap ikan dari yang ukuran terkecil sampai yang besar dan dioperasikan di perairan yang dangkal dan cenderung merusak kondisi dasar perairan.

\section{KESIMPULAN}

Kesimpulan yang dapat diambil dari penelitian ini terdapat tiga jenis ikan hasil 
tangkapan dominan yaitu ikan layang, ikan kembung dan cumi cumi. Selama lima tahun terakhir (dari tahun 2015 - 2019), produksinya cenderung mengalami penurunan yang signifikan, demikian pula dengan produktivitasnya juga mengalami penurunan. GT kapal, HP kapal, jumlah trip, jumlah ABK dan panjang jaring merupakan input faktor yang menjadi pembanding dalam menentukan produktivitas kapal purse seine di Jepara. Trend produktivitas purse seine yang menurun disebabkan oleh kompetisi antar alat tangkap yang beroperasi dalam daerah penangkapan yang sama, kurang optimalnya dalam mengelola input faktor, kecenderungan sumberdaya ikan yang semakin berkurang dan kondisi alam yang sangat dinamis. Keadaan ini akan mengakibatkan pendapatan nelayan juga menurun dan memberikan peluang untuk pemanfaatan input faktor yang tak terkendali.

\section{SARAN}

Mengacu pada menurunnya produksi ikan hasil tangkapan dominan serta produktivitas purse seine di TPI Ujungbatu Jepara, maka perlu adanya upaya pengendalian terkait penangkapan yang dilakukan. Salah satunya alat tangkap yang digunakan, harus mengacu pada ketentuan teknis yang sudah ada. Perlu dikaji lebih jauh tentang faktorfaktor lain yang mempengaruhi produksi purse seine.

\section{UCAPAN TERIMA KASIH}

Penulis mengucapkan terimakasih kepada Kepala TPI Ujungbatu Jepara dan staf serta kepada para nelayan purse siene yang telah banyak membantu penulis dalam mengumpulkan data di lapangan.

\section{DAFTAR PUSTAKA}

Aliredjo S. 2015. Teknika Kapal Penangkap Ikan. Jakarta: Direktorat Pembinaan Sekolah Menengah Kejuruan.

Ayunda N, Sapota MR, Pawelec A. 2018. The Impact of Small-Scale Fisheries Activities Toward Fisheries Sustainability in Indonesia. In Interdisciplinary Approaches for Sustainable Development Goals. Cham: Springer. (2018): 147167.

[BBPPI] Balai Besar Pengembangan Penangkapan Ikan. 2008. Klasifikasi
Alat Penangkapan Ikan di Indonesia. BBPPI. Semarang.

[BSN] Badan Standarisasi Nasional. 2010. Ukuran Utama Jaring Lingkar Bertali Kerut (Purse Seine). RSNI Prociding 2010. BBPPI. Semarang.

Damayanti HO. 2020. Produktivitas Perikanan Tangkap Jaring Purse Seine. Jurnal Litbang:Media Informasi Penelitian, Pengambangan dan IPTEK. 16(1): 29-46.

Diniah. 2008. Pengenalan Perikanan Tangkap. Bogor. Departemen Pemanfaatan Sumberdaya Perikanan FPIK. Bogor: IPB.

Fatimah S. 2017. Analisis Pengaruh Faktorfaktor Produksi terhadap Ikan Hasil Tangkapan Nelayan Mini Purse Seine di UPT Pelabuhan Perikanan Pantai Tasik Agung Rembang. [Skripsi]. Malang (ID): Universitas Brawijaya.

Hariyanto T, Baskoro MS, Haluan J, Iskandar $\mathrm{BH}$. 2008. Pengembangan Teknologi Penangkapan Ikan berbasis Potensial di Teluk Lampung. Jurnal Saintek Perikanan. 4(1):16-24.

Hertanto S, Nur KN, Astuti P. 2013. Peran Pemerintah Daerah Dalam Pengelolaan Tempat Pelelangan Ikan Di Kabupaten Jepara. Journal of Politic and Government Studies. 2(2): 411425.

Hufiadi. 2008. Pengukuran Efisiensi Teknis Perikanan Purse Seine di Pekalongan. [Tesis]. Bogor: Institut Pertanian Bogor.

Jaya MM, Wiryawan B, Simbolon D. 2017. Keberlanjutan Perikanan Tuna di Perairan Sendangbiru Kabupaten Malang. Albacore. 1(1): 111-125.

Keputusan Menteri Kelautan dan Perikanan Republik Indonesia. 2014. Produktivitas Kapal Penangkap Ikan. No.61/KEPMEN-KP/2014.

Limbong I, Wiyono ES, Yusfiandayani R. 2017. Faktor-Faktor yang Mempengaruhi Hasil Produksi Unit Penangkapan Pukat Cincin di PPN Sibolga, Sumatera Utara. ALBACORE. I(1): 8997.

Nurhayati M, Wisudo SH, Purwangka F. 2018. Produktivitas dan Pola Musim Penangkapan Tuna Madidihang (Thunnus albacares) di Wilayah 
Pengelolaan Perikanan 573. Akuatika Indonesia. 3(2): 127-135.

Pujianto, Boesono H, Wijayanto D. 2013. Analisis Kelayakan Usaha Aspek Finansial Penangkapan Mini Purse Seine dengan Ukuran Jaring yang Berbeda di PPI Ujungbatu Jepara Kabupaten Jepara. Journal Of Fisheries Resources Utilization Management and Technology. 2(2): 124-133.

Ravianto J. 1996. Produktivitas. Jakarta: Ghalia Indonesia

Simbolon D, Wiryawan B, Wahyuningrum PI, Wahyudi H. 2011. Tingkat pemanfaatan dan pola musim penangkapan Ikan Lemuru di Perairan Selat Bali. Buletin PSP. 19(3): 293-307.

Suharno, Widayati T. 2015. Kebijakan Pengelolaan Usaha Perikanan Tangkap Nelayan Skala Kecil di Pantura Jawa Tengah. Prosiding Seminar Nasional Multi Disiplin IImu. ISBN 978-979-3649-81-8. Penerbit Unisbank.

Suman A, Satria F, Nugraha B, Priatna A, Amri K, Mahiswara. 2018. Status Stok Sumber Daya Ikan Tahun 2016 di Wilayah Pengelolaan Perikanan Negara Republik Indonesia (WPP NRI) dan Alternatif Pengelolaannya. Jurnal Kebijakan Perikanan Indonesia. 10(2): 107-128.
Supeni EA, Tanjaya E, Dobo J. 2014. Potensi dan Tingkat Pemanfaatan Sumberdaya Ikan Tongkol (Auxis thazard) di Perairan Maluku Tenggara Provinsi Maluku. WWF Prosiding. Simposium Nasional Pengelolaan Perikanan Tuna Berkelanjutan. hlm: 97-104.

Wahju RI, Zulkarnain, Mara, KPS. 2011. Estimasi Musim Penangkapan Layang (Decapterus spp) yang Didaratkan Di PPN Pekalongan, Jawa Tengah. Buletin PSP. 19(1): 105-113.

Wahyono A. 2003. Petunjuk Teknis Pembuatan dan Pengoperasian Alat Penangkap Ikan Pukat Cincin 280 meter. Semarang: Balai Pengembangan Penangkapan Ikan.

Wiyono ES. 2012. Analisis Efisiensi Teknis Penangkapan Ikan Menggunakan Alat Tangkap Purse Seine di Muncar. Jurnal Teknologi Industri Pertanian. 22(3):164-172.

Wiyono ES, Hufiadi. 2014. Measuring the Technical Efficiency of Purse Seine in Tropical Small-scale Fisheries in Indonesia. Asian Fisheries Science. 27: 297-308.

Wudji A, Suwarso. 2015. Perkembangan Hasil Tangkapan dan Musim ikan Tongkol (Auxis spp.) di Perairan Prigi. Prosiding Simposium Nasional Pengelolaan Perikanan Tuna Berkelanjutan. WWFIndonesia 1-7. 